\title{
INTERNAL CONTROL MECHANISM AND EXECUTION OF PROJECTS IN PUBLIC SECTOR: EVIDENCE FROM ENUGU STATE, NIGERIA
}

\author{
Oraka, Azubike 0. \\ Department of Accountancy \\ Nnamdi Azikiwe University, awka \\ Mail: zubbike@gmail.com \\ Ikwor, Uwakwe K. \\ Department of Accountancy \\ Nnamdi Azikiwe University, Awka \\ Mail: uwakwe.ikwor@yahoo.com \\ Afodigbueokwu, Hillary E. \\ Department of Accountancy \\ Nnamdi Azikiwe University, Awka \\ Mail: hilachuks@gmail.com
}

\begin{abstract}
The study determined the influence of internal control systems on project execution rate in Enugu State, the study therefore sought to: ascertain the influence of accounting control and administrative and operational control on the execution of projects in Enugu State public sector. The research design adopted for this study is survey design. This was adopted because of the nature of the data which is basically primary data generated through questionnaire method. The Researchers used questionnaires as the major source of data collection which was administered to 350 respondents of various ministries in Enugu State, Nigeria. The data collected were analyzed and tested using regression analysis with aid of E-view version 9. From the analysis, the result shows that Accounting Control, and Administrative and Operational Control was found to have positive and statistically significant influence on capital project execution rate in Enugu State public sector. The researchers therefore, recommend that various ministries in Enugu State that are looking for a way to reduce high rate of capital project abandonment in the state should consider strengthening their level of accounting control implementation.
\end{abstract}

Keywords: Accounting Control, Administrative and Operational Control, and Execution of Projects 


\section{Introduction}

Internal controls (ICs) are very fundamental component of the risk management systems. ICs can be applied to several parts of a business, whether "strategic, financial, operational and compliance" (Financial Reporting Council, 2014). According to Adeoye and Adeoye (2014), "internal control system is a topical issue following global fraudulent financial reporting and accounting scandals in both developed and developing countries". For any organization to maximize its finances and safeguard its assets, it must be able to manage its business processes which are one reason why ICs are very crucial.

The subject of internal controls is not new but then there have been series of fraudulent practices both in the past and in recent times. The cases of Enron, Parmalat, Cadbury among others are evidences around us. The instances of breakdown in controls have brought about formulation of different frameworks, codes and regulations like the COSO "1992 Framework" (updated 2013) in the United States, Sarbanes-Oxley Act of 2002 (U.S.), Combined Code of Corporate Governance 2003 (UK), Turnbull guidance on Internal Control (revised in October 2005) in the UK, SEC code of 2003 (updated 2011, 2014) in Nigeria. With all these frameworks in place, the challenges with the breakdowns of ICs should have been over. However, studies in Nigeria (Gbegi \& Adebisi (2015), Alao \& Amoo (2014), Abiola \& Oyewole (2013), Hamilton \& Gabriel (2012), Akinyomi (2010)) show that most internal control systems are weak, inadequate or not complied with, yet these frameworks are in place to guide companies with respect to compliance with internal controls. A system of effective internal controls is a critical component of both public and private sectors management and a foundation for the safe and sound operation of these organizations. In other words, strong internal controls can help to ensure that the goals and objectives of an organization will be met, that the organization will achieve long-term profitability targets(if a private sector), and maintain reliable financial and managerial reporting. Such a system can also help to ensure that the organization will comply with laws and regulations as well as policies, plans, internal rules and procedures, and decrease the risk of unexpected losses or damage to the organization's reputation (Ofor, 2019).

El- Rufai (2012) explains that when projects fail, the usual reason given is lack of fund whereas it is the pre-contract mishaps and project management deficits that are the fundamental causes of project failures in Nigeria. The study explains that section 4 (2) of the Public Procurement Act No.14, 2007 requires that no contract should be awarded if funds are not available from the onset. "'these statutory functions have been hampered by lots of challenges, including the late passage of the annual appropriation Acts by NASS and abandonment of procurement processes by the MDAs if favoured bidders turn out to be unsuccessful'" (El- Rufai, 2012,). Should the problem of stewardship persist, Nigeria's development reforms would not be accomplished. This study therefore proposes to investigate the effect of internal control systems in the execution of capital projects in Ministries in Enugu State, Nigeria.

Scholars have made some achievements in the area of internal control system in public sector both within and outside Nigeria which show that most internal control systems in the public sector are weak, inadequate or not complied to in the public sector and yet they have internal control frameworks in place to guide them. Furthermore, Ishola, Abikoye and Olajide (2015) examined effect of internal control system in Nigeria public sector and discovered that establishment of internal control plays a vital role in prevention of fraud and irregularities. The study pointed out that it is obvious that the act of fraud has become the order of the day 
in the public sectors in Nigeria due to inefficient management culture on fraud which indicates absence of internal control system in public sectors in Nigeria. Amudo and Inanga (2009) in their own study, evaluated internal control systems in Uganda and found that effective internal controls system are lacking in public sectors projects in Uganda. However, none of these studies investigated the influence of internal control systems in project execution rate in Enugu State public sector, the study therefore sought to:

1. Ascertain the influence of accounting control on the execution of projects in Enugu State public sector.

2. Determine the influence of administrative and operational control on the execution of projects in Enugu State public sector.

\section{Review of Related Literature}

\section{Accounting Control}

This is the type of control established to ensure that there is completeness, accuracy and validity of the financial information produced by the system (Ofor, 2019). According to Odum and Odum (2017), Controls over information processing- A variety of control activities are used in information processing. Examples include edit checks of data entered, accounting for transactions in numerical sequences, comparing file totals with control accounts, and controlling access to data, files and programs.

Enugu State Internal Control Manual (ENSG, 2010), stipulates that Control on core financial activities are implemented to prevent or reduce the risks that can impede accomplishment of government programmes. The control activities could be directive, preventive, detective or corrective. Important controls that are implemented on core financial activities include: (i) Documentation Controls (ii) Approval and Authorisation Controls (iii) Verification Controls (iv) Supervisory Controls (v) Segregation of Duties Controls (vi) Physical and Security Controls on non-current Assets (vii) Reporting Controls. An effective internal control system requires that there is appropriate segregation of duties and that personnel are not assigned conflicting responsibilities. Areas of potential conflicts of interest should be identified, minimized, and subject to careful, independent monitoring.

\section{Administrative and Operational Control}

According to Ofor (2019), administrative and operational control is the type of control that is established in an organization to ensure an orderly and efficient execution of administrative and operational activities. Furthermore, COSO (2013) maintained that administrative and operational control includes control activities that involve the supervision or monitoring of operations, such as the observation or review of on-going operational activity.

ENSG (2010) internal control manual stipulate that such control involves also the verification or review of documents to determine the completeness, accuracy, authenticity and or validity of transactions, events or information contained in a document. It is carried out to ensure that activities are executed in accordance with directives of superior officers or the attached supporting documents. The following steps are taken to implement Verification or Reviews Controls in the MDAs: 
Primary Reviews: All documents are usually reviewed by the person preparing it before forwarding to the next officer. It is done by reading the document all over again. This is a primary control.

Secondary Reviews: The Supervisor of staff who prepared the document also review the document before it leaves the Department, Section or Unit. This review is evidenced by the signature of the Supervisor.

Prepayment Audit: All payment documents eligible for prepayment audit are sent to the Internal Audit Unit to carry out a thorough review before releasing funds to the payee. (v) Return of Documents: Any inconsistency in payment or supporting documents usually attract rejection and return of such documents during reviews.

\section{Project Execution Rate}

Project execution rate simply means the rate at which awarded contracts are been fully funded and completed within the stipulated timeframe (Ofor, 2019). On the other hand, project execution rate in this concept is the rate at which capital projects are been executed and fully completed in public sector rather than been abandoned during the course of its execution. In project execution, appropriate measures are taken to assess the risks the MDAs are exposed to, from both within and outside, in executing the Projects. The aim is to identify such risks and make contingency plans in advance to cushion the effects whenever such risk arises. Some risks are very fundamental that the project may be frustrated if they occur, hence adequate measures are taken to forestall the situation. The likely risks the government usually face include (i) Drop in the amount of revenue allocated or generated (ii) Delay in the realisation of revenue (iii) Impact of inflation on costs, leading to increase in expenditure (iv) Natural disaster (v) Changes in government (vi) Variation in oil prices and production volume (vii) Corruption of government officials (viii) Changes in legislation and government policy (ix) Industrial Relations problems and labour unrest (x) Increase in funding cost. Delays by the Contractor to meet the target time set for the Project (ENSG Internal Control Framework, 2010).

To manage funding risks, projects may be segmented into phases of manageable sizes. Adequate funds are provided before embarking on such projects. Before funds are provided, the project must go through due process, i.e. designing, analysing, quantifying and evaluation of contractors to ascertain their capability and readiness to execute the project within the expected delivery time.

\section{Empirical Studies}

In another study done by Abugri (2015) assessed the internal control systems of public institution in Ghana, he argued that there have been several cases of embezzlement of funds and misuse of resources in Public institutions though such institutions have several rules and control measures to Guide their operations. The descriptive research method was employed in the study. The population was all staff at the Polytechnic in the year 2014-2015. The findings revealed that management does not communicate to the staff of new control policies introduced. Again the findings indicated that the control systems at the Polytechnic are quite effective and are directed towards the detection and prevention of fraud and error. Kisanyanya (2018) ascertained the internal control systems on financial performance of public institutions of higher learning in Vihiga County, Kenya. The study was anchored on 
agency theory, stewardship theory, positive accounting theory and attribution theory. The study used a descriptive research design. The target population of respondents was 140 employees in the four institutions studied whereas the sample size was 96 employees. Primary data was collected from sample population using semi-structured questionnaires. Descriptive and multiple regression analysis were used to analyze data. The study found that the institutions had adequate and effective control activities which included regular internal audit reports, adequate segregation of duties in the finance and accounts departments and physical controls to prevent excess allocated funds. Risk assessment was found to have a positive significant effect on the financial performance of the institutions under study.

Sharma and Nabil Senan (2019) examined effectiveness of internal control system in selected Saudi Banks in Saudi Arabia. The study concluded that the Banks in Saudi Arabia have satisfactory internal control system. The study statistically proved that there is significant difference in effectiveness of Internal Controls in the Selected Saudi Banks. Umaru and Umar (2018) determined the effect of internal control systems on the performance of commercial banks in Nigeria. A survey method was employed and the study used stratified random sampling, The questionnaire is a 5 point Likert-scale while the data collected was analyzed using Statistical Package for the Social Sciences (SPSS) version 23 (v23) and Smart PLS 3. The findings of the study revealed that there is a positive and significant relationship between the four components of internal control (control environment, control activities, monitoring and risk assessment) and bank performance. Muhunyo (2018) investigated the effect of internal control systems on financial performance in public institutions of higher learning in Nairobi City County. The study used a descriptive research design. Primary data was collected from sample population using open and closed ended questionnaires. A multiple linear regression was also used to analyze the relationship between the dependent and independent variable. The study realized that the control environment, risk assessment, control activities and information and communication as indicators of internal control systems have a significant influence on the financial performance of the institutions of higher learning in Nairobi City County, Kenya.

\section{Methodology}

The research design adopted for this study is survey design. This was adopted because of the nature of the data which is basically primary data generated through questionnaire method.

The population of the study involved the accountants and auditors of various ministries in Enugu state, Nigeria. This research focused on the state government as government has a high number of abandoned projects both capital and non-capital projects as well. Also, the State is a large employer of public servants such as accountants and auditors, who are well informed about the issue of internal control system framework of the State. The researchers used simple random sampling to select three hundred and fifty staff of these ministries as the sample size.

The Researcher used questionnaires as the major source of data collection which was contained 25 items on the study variables. These questions were structured on a five point likert scale, thus: Strongly Agree (SA), Agree (A), Disagree (D), Strongly Disagree (SD) and Undecided (U).

The dependent variable for this study is project execution rate (PRER) while our independent variable is internal control system measured as Accounting Control (ACCT), Administrative 
and Operational Control (ADOC), Regression analysis was used to test the two hypotheses with aid of E-view version 9.

\section{Model Specification}

PRER $=\lambda_{0}+\lambda_{1} A C C T C+\lambda_{2} A D M P C++\mu$.

Where:

PREE $=$ Project Execution Rate (dependent variables)

ACCT $=$ Accounting Control

ADMPC $=$ Administrative and operational control

$\lambda_{0}$ is the constant term; $\lambda_{1}$ to $\lambda_{4}$ represents the coefficients of our independent variables'

$\mu$ is the error term.

\section{Decision Rule}

The decision for the hypotheses is to accept the alternative hypothesis if the P-value of the test statistic is positive and significant at $5 \%$ significant level. $\mathrm{P}$-value less than $5 \%$, reject, $\mathrm{P}$ value greater than $5 \%$ then do not reject.

\section{Analysis and Interpretation of Data}

\section{Data Analysis}

\section{Table 1: Descriptive Statistics of the Variables}

$\begin{array}{lccc}\text { Mean } & \text { PROER } & \text { ACCTC } & \text { ADMOPC } \\ \text { Median } & 4.150000 & 4.046667 & 3.608095 \\ \text { Maximum } & 4.200000 & 4.200000 & 3.600000 \\ \text { Minimum } & 4.600000 & 4.600000 & 4.600000 \\ \text { Std. Dev. } & 3.000000 & 3.000000 & 2.200000 \\ \text { Skewness } & 0.317621 & 0.346429 & 0.431052 \\ \text { Kurtosis } & -1.153705 & -1.059950 & -0.540685 \\ \text { Jarque-Bera } & 4.106726 & 3.758812 & 2.937974 \\ \text { Probability } & 114.6072 & 88.72106 & 20.53114 \\ \text { Sum } & 0.000000 & 0.000000 & 0.000035 \\ \text { Sum Sq. Dev. } & 1743.000 & 1699.600 & 1515.400 \\ \text { Observations } & 42.27000 & 50.28533 & 77.85248 \\ \text { Source: Researchers computation }(2021) & 350 & 350\end{array}$

Table 1 shows the mean (average) for each of the variables, their maximum values, minimum values, and standard deviation and Jarque-Bera (JB) statistics (normality test). The result gave some insight into the nature of the selected variables used in this study. Firstly, the table reveals that averagely 4.15000 of the respondents, about $91 \%$ of the respondents are fully aware of internal control systems obtainable in various ministries, in Enugu State This disclosure is encouraging and completely over-whelming as it helps to increase the researchers confidence level that their data is reliable as high number of respondents are not ignorant of internal control systems existing in public sector of the State. 


\section{Test of Hypotheses Formulated}

\section{Table 2: Pool Regression Result between ACCR, ADOC and PRER}

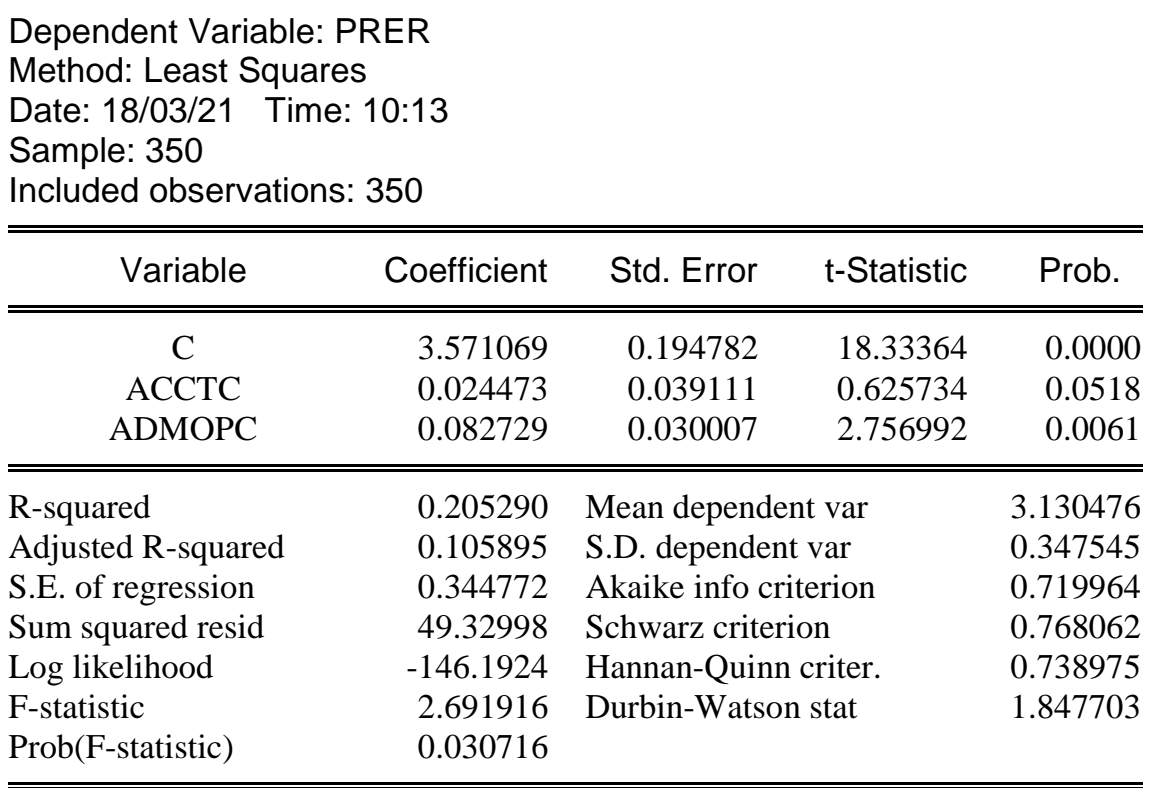

Source: Researcher's computation (2021)

In testing for cause-effect relationship between the dependent and independent variables in PRER model, the OLS pooled regression results shows that from the PRER result that the Rsquared and adjusted R-squared values were 0.205290 and 0.105895 respectively. This indicates that all the independent variables jointly explain about $21 \%$ of the systematic variations in PRER rate in public sector in Selected States in South-South Nigeria.

Test of Autocorrelation: using Durbin-Waston (DW) statistics which we obtained from our regression result in table 2, it is observed that DW statistics is 1.85 and an Akika Info Criterion and Schwarz Criterion which are -0.72 and 0.77 respectively also further confirms that our model is well specified. In addition to the above, the specific findings from each explanatory variable are provided as follows:

\section{Hypothesis One}

Ho: The accounting control has no significant effect on the execution of projects in Enugu State public sector.

Accounting Control: based on the t-value of 0.625734 and p-value of 0.05 , was found to have a positive influence on our dependent variable and this influence is statistically significant as its p-value is equal to 0.05 values. This result, therefore suggests that we therefore accept our alternative hypothesis which states that the accounting control has significant influence on the execution of projects in Enugu State public sector.

\section{Hypothesis Two}

Ho: The administrative and operational control has no significant effect on the execution of projects in Enugu State public sector. 
Administrative and Operational Control: based on the t-value of 2.756992 and p-value of 0.01 , was found to have a positive influence on our dependent variable and this influence is statistically significant as its $\mathrm{p}$-value is equal to 0.05 values. This result, therefore suggests that we therefore accept our alternative hypothesis which states that the administrative and operational control has significant influence on the execution of projects in Enugu State public sector.

\section{CONCLUSION}

From the analysis done in this study, the outcome from the result shows that Accounting Control was found to have positive and statistically significant influence on capital project execution rate in Enugu State public sector. The result also shows that Administrative and Operational Control was found to be positive and statistically significant influence on capital project execution rate in Enugu State public sector. It is further established that internal control variables such as accounting control, administrative and operational control, are needed to be effectively implemented in the MDAs of the State, for the reason that effective accounting control is the bedrock of all other controls. Therefore, this is a clarion call to accountants and accounting profession to take up this challenge of cleaning our nation by adhering strictly to the accounting standards.

Based on the findings of the study, the researchers recommend that; various ministries in Enugu State that are looking for a way to reduce high rate of capital project abandonment in the state should consider strengthening their level of accounting control implementation. Besides, they also should consider strengthening their level of administrative and operational control. 


\section{REFERENCES}

Abiola, I. \& Oyewola, A.T.(2013). Internal control system on fraud detection: Nigeria experience, Journal of Accounting and Finance, 13(5), 141-152.

Abugri, S. S.(2015). Assessing the internal control systems of public institution: A case study of Tamale Polytechnic), A thesis submitted to Department of Accounting and Finance, Kwame Nkrumah University of Science and Technology School of Business, 1-75. Retrieved online at www.school of business KNUST.

Akinyomi, O.J.(2010). The effect of internal control system on Nigeria Banks, International Journal of Accounting, 2(2), 23-29.

Alao, A.A \& Amoo, a.a(2014). Enhancing the performance of electricity distribution Companies in Nigeria via internal control system, Research Journal of Finance and Accounting, 5(22), 197-214.

Amudo .A. \& Inanga, E.L.(2009). Evaluation of internal control system: A case study from Uganda, International Research Journal of Finance and Economics, 27, 124-144.

Ayodele, O. \& Michael, A. (2014). Abandonment of Construction Projects in Nigeria: Causes and Effects, Journal of Emerging Trends in Economics and Management Sciences 2 (2), $142-145$.

COSO(2013), Internal control framework, Retrieved online @www.pwc.com/us/en/forensicservics/publications/assets/pwc-new-internal-control-framework-litigation-counselperspective.

El- Rufai, N. (2012). The Tragedy of Abandoned Projects. Retrieved on December 8, 2013 from http://www.premiumtimeng.com/opinion.

ENSG(2010). Internal Control Manual for Enugu State Government, Retrieved online @ www. Enugu state 3_internal_control_manual...

Hamilton,D.I. \& Gabriel, J.M.N.(2012). Dimension of fraud in Nigeria quoted firms, American Journal of Social and Management Sciences, 3(3), 112-120.

Ishola, S.A., Abikoye, O.A. \& Olajide, R.A.(2015). Effect of internal control system in Nigeria public sector: A case of Nigeria National Petroleum Corporation, International Journal of Economic, Commerce and Management, 111(6), 1-13.

Kisanyanya, A.G.(2018). Internal control systems and financial performance of public institutions of higher learning in Vihiga County, Kenya. IOSR Journal of Business and Management (IOSR-JBM): 20(4) (April.: 31-41)

Odum,A.N \& Odum, G. C.(2017). Essentials of Auditing, $2^{\text {nd }}$. Edition, SCOA Heritage Nig. Ltd, Anambra State, Nigeria, 90-94.

Ofor, N.T.(2019). The internal control syetems in the public and private sectors.Association of National Accountants of Nigeria Mandatory Continuing Professional Development(MCPD) Programme,50-100. 
International Journal of Advanced Academic Research (Social \& Management Sciences) | ISSN: 2488-9849 Vol. 7, Issue 3 (March, 2021) | www.ijaar.org

Journal DOI: www.doi.org/10.46654/ij.24889849

Article DOI: www.doi.org/10.46654/ij.24889849.s7318

Sharma, R.B. \& Nabil Senan, A.M.(2019).A study on effectiveness of internal control systems in selected banks in Saudi Arabia. Asian Journal of Management Sciences; $8(1): 41-47$. 